\title{
MANGO (Mangifera indica L.) LEAVES WASTE/POLYVINYL ACETATE BIOCOMPOSITE FOR BUILDING MATERIALS APPLICATION
}

\author{
MASTURI ${ }^{1 *}$, DANTE ALIGHIRI ${ }^{2}$, WIDYA NURUL JANNAH ${ }^{1}$, RIFUL MAZID MAULANA ${ }^{1}$, \\ ULUL AMRI $^{1}$, SUSILAWATI ${ }^{3}$ and SUNARNO ${ }^{1}$

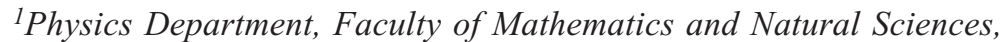 \\ Universitas Negeri Semarang, Indonesia \\ ${ }^{2}$ Chemistry Department, Faculty of Mathematics and Natural Sciences, \\ Universitas Negeri Semarang, Indonesia \\ ${ }^{3}$ Physics Department, Faculty of Science and Technology, Universitas Islam Negeri Walisongo, \\ Semarang, Indonesia \\ *E-mail: masturi@mail.unnes.ac.id
}

Accepted 22 April 2020, Published online 6 July 2020

\begin{abstract}
A leaves waste biocomposite was produced via a simple mixing and hot-pressing process. Using mango (Mangifera indica L.) leaves waste as a filler and polyvinyl acetate (PVAc) as a binder, the biocomposite was synthesized at pressure and temperature of 3 metric tons and $40^{\circ} \mathrm{C}$, respectively, for 20 minutes. The weight fraction of leaves waste varied obtaining a composite having maximum compressive strength, i.e., $37.82 \mathrm{MPa}$ for leaves waste fraction of $0.62(\mathrm{w} / \mathrm{w})$. This strength is comparable to several stones such as sandstone stone, limestone, clay brick, aspen wood, and pinewood usually used as building materials. Therefore, the biocomposite is acceptable for building materials application.
\end{abstract}

Key words: Mango leaves waste, polyvinyl acetate, biocomposite, compressive strength

\section{INTRODUCTION}

The composite research is one of the emerging studies currently done due to its utilization and applications in several fields relating such as in electricity, magnetism and mechanical properties (Kumagai \& Sasaki, 2009; Taghvaei et al., 2010; Zeng et al., 2012; Ko et al., 2014; Wang et al., 2014). Also, particularly the mechanical composite research has been done for a large number of applications, such as automotive and building industries (Holbery \& Houston, 2006; Masturi et al., 2010; Rêgo et al., 2015). One of the raw materials that enable to be used for a mechanical composite is solid waste, especially leaves waste. Some works using the solid waste as have been done, such as Hadiyawarman et al. (2008) making the solid waste for composite using epoxy resin as a matrix. Kumagai and Sasaki (2009) produced silica composite from agricultural waste. Then, Masturi et

* To whom correspondence should be addressed. al. (2010) also developed leaves waste composites using polyurethane.

On the other hand, mango leaves is a kind of crop waste that is rich in resources (Pan et al., 2018), and currently not used for any commercial application. Therefore, the leaves of the mango only become an environmental problem. Previous studies have shown that mango leaves are rich in flavonoids (Berardini et al., 2005), such as quercetin, gallic acid, gallotannins, and iriflophenones (Barreto et al., 2008; Zang et al., 2014; Fernández-Ponce et al., 2015). This flavonoid content is the reason for the enormous potential of mango leaf in large applications of many industries.

Therefore, in this work, we have developed a leaves waste biocomposite using the phenolic or flavonoid compounds of the fiber and minerals in mango leaves associated and bound with PVAc into matrix. The PVAc was used since its binding properties make up strong mechanical properties of composite and has been widely used in several composites engineering, such as in-home waste 
composite (Masturi et al., 2011a), conducting composite (Eraldemir et al., 2008), and silver-iron photocatalytic composite (Ghanbari et al., 2016).

\section{MATERIALS AND METHODS}

\section{Materials}

The Mango (Mangifera indica L.) leaves waste was collected from Central Java province of Indonesia. Commercial polyvinyl acetate (PVAc) was purchased from Bratachem, Semarang, Indonesia. All the chemical were pure analytical reagents from Merk.

\section{Sample preparation}

The Mango (Mangifera indica L.) leaves waste was cleaned using water, then dried at room temperature $\left(50-60^{\circ} \mathrm{C}\right)$ for 20 minutes. The dried mango leaves were pulverized using a crushermachine.

\section{Synthesis of biocomposite}

The powder of mango (Mangifera indica L.) leaves was mixed with several weights of PVAc. The PVAc-solid waste mixture then was hot-pressed at pressure and temperature of 4 metric ton and $80^{\circ} \mathrm{C}$ respectively on a mold of $4 \mathrm{~cm}$ in diameter. Finally, the sample was released from the mold to measure its compressive strength.

A compressive strength characterization was performed to test the mechanical strength of composite produced by cutting the sample in the small cubic form (ASTM C0109M-02). This measurement used Torsee Tokyo Testing Machine MFG Ltd. equipped with Load Cell with a relation (Masturi et al., 2010):

$$
\sigma=\frac{4 P}{\pi D^{2}}
$$

With $P$ is a maximum force loaded making a composite crushed, and $D$ is the composite diameter.

\section{RESULTS AND DISCUSSION}

The strength of composite produced varies as the weight fraction of leaves waste with the maximum strength attains $37.82 \mathrm{MPa}$ for leaves weight fraction of $0.62(\mathrm{w} / \mathrm{w})$ (Figure 1). The variation of strength was commonly governed by surface interaction, especially van der Waals interaction between the atoms of the leaves waste and polyvinyl acetate. In a certain amount, the interaction in atomic-scale significantly increases the strength.

The improvement of biocomposite was governed by interaction-pairs of leaves waste and its polymer. Using the effective interaction, the strength change can be explained using the interaction appearing between the polymer and the leaves waste, where the optimum interaction occurs when all of the polymer surfaces interact with the leaves waste particles surfaces, and it makes the composite strength maximum (Tan et al., 2007; Masturi et al., 2011a; 2016). Even, with polyvinyl

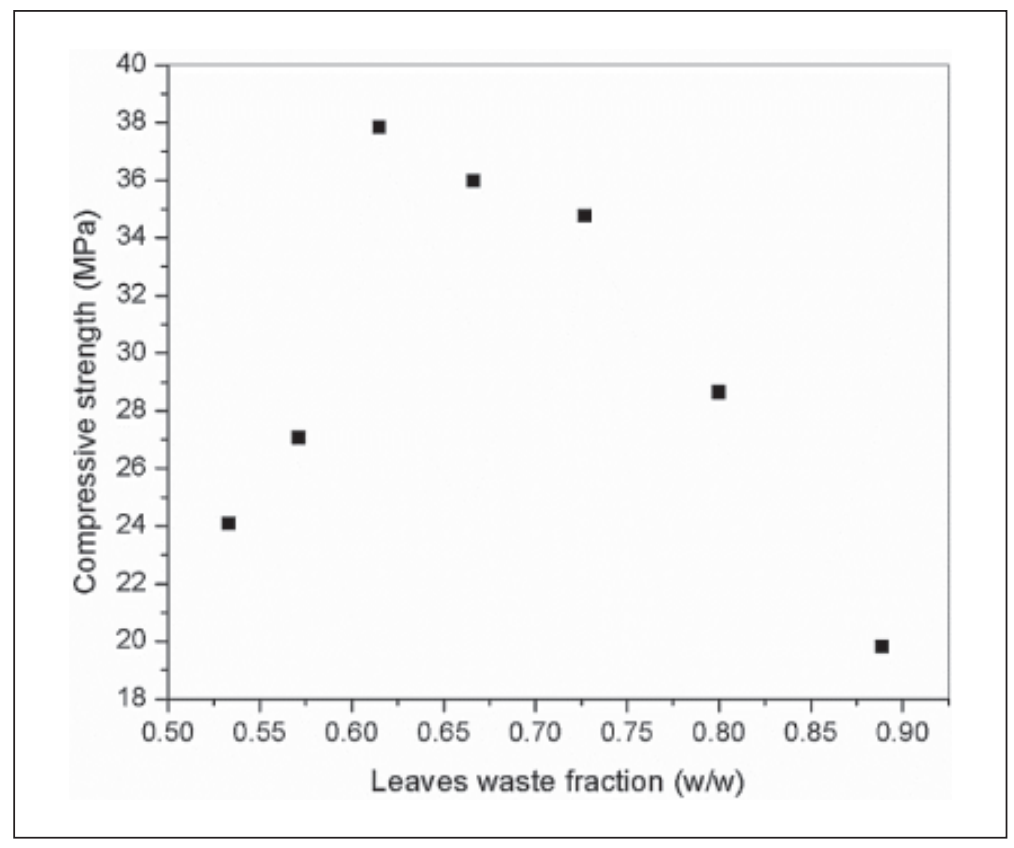

Fig. 1. Compressive strength as leaves waste fraction (w/w) with the optimum fraction is $0.62(\mathrm{w} / \mathrm{w})$ for compressive strength of $37.82 \mathrm{MPa}$. 


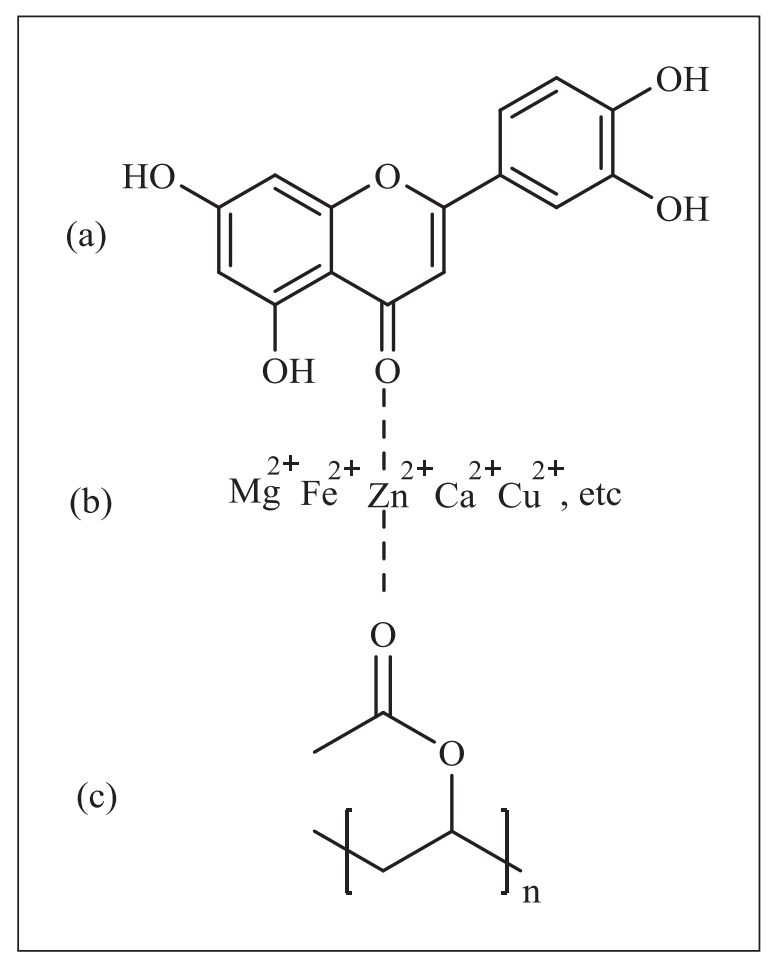

Fig. 2. Illustration of Van der Waals interaction (represented by a dashed line) between (a) quercetin as the main of flavonoid in mango leaves (Wu et al., 2010), (b) mineral in mango leaves (Okwu \& Ezenagu, 2008), and (c) PVAc's carbonyl group.

acetate having carbonyl group the interaction especially occurs between its oxygen and some atoms of leaves consisting of oxygen, hydrogen and some metals (Figure 2), however in this work the measurement of composition and amount of the atoms, molecules, and ions contained in the leaves waste has not been addressed. This interaction that is usually called van der Waals interaction mainly governs the composite strength (Volkov et al., 1990; Singh \& Bansal, 2015; Liu et al., 2010).

The attainment of strength to $37.82 \mathrm{MPa}$, then decreases due to leaves addition is fulfilling the pair-interaction between polymer leaves surface. For the initial fraction with a smaller amount of leaves, the interaction has not reached yet maximum since the amount of PVAc is still more significant. Then the addition of leaves wastes up to $0.62(\mathrm{w} / \mathrm{w})$ affects the improvement of pair-interaction of the latter waste with the PVAc so that the surface of polymer correctly interacts with the leave particles surface, wherein this condition the fraction of 0.62 was called as an optimum fraction. Further, the leaves addition, excluding the optimum fraction presents the new unpaired surface governing the decreasing of the strength (Masturi et al., 2011b; Wang et al., 2015).
The strength of composite produced is very comparable to some materials mainly used in building materials application, such as sandstone stone (43 MPa), limestone (40 MPa), clay brick (20 $\mathrm{MPa})$, aspen wood (36 MPa) and pinewood (41 MPa) (Brencich \& Sterpi, 2006; Green et al., 2002; Nazir et al., 2013; Abouhussien et al., 2015). It means the composite is very potential to be used in a building application.

\section{CONCLUSION}

We successfully made leaves waste biocomposite using polyvinyl acetate matrix with the maximum strength attaining $37.82 \mathrm{MPa}$ for 0.62 mango leaves waste-fraction $(\mathrm{w} / \mathrm{w})$. This strength is comparable to some building materials used widely in building fields, such as sandstone stone, limestone, clay brick, aspen wood, and pinewood. It showed that the biocomposite produced has potential to be used as building materials application.

\section{ACKNOWLEDGMENT}

This research was funded by The Ministry of Research, Technology and Higher Education of Republic of Indonesia.

\section{REFERENCES}

Abouhussien, A.A., Hassan, A.A.A. \& Hussein, A. 2015. Effect of expanded slate aggregate on fresh properties and shear behaviour of lightweight SCC beams. Magazine of Concrete Research, 67(9): 433-442.

Barreto, J.C., Trevisan, M.T.S., Hull, W.E., Erben, G., De Brito, E.S. \& Pfundstein, B. 2008. Characterization and quantitation of polyphenolic compounds in bark kernel, leaves, and peel of mango (Mangifera indica L.). Journal of Agricultural and Food Chemistry, 56: 55995610 .

Berardini, N., Fezer, R., Conrad, J., Beifuss, U., Carle, R. \& Schieber, A., 2005. Screening of mango (Mangifera indica L.) cultivars for their contents of flavonol O- and xanthone C-glycosides, anthocyanins, and pectin. Journal of Agricultural and Food Chemistry, 53: 1563-1570. 
Brencich, A. \& Sterpi, E. 2006. Compressive strength of solid clay brick masonry: calibration of experimental tests and theoretical issues, in Structural Analysis of Historical Constructions edited by P.B. Lourenço (New Deli, 2006), pp. $1-8$.

Eraldemir, O., Sari, B., Gök, A. \& Ünal, H.I. 2008. Synthesis and characterization of polyindole/ poly(vinylacetate) conducting composites. Journal of Macromolecular Science Part A, 45(3): 205-211.

Fernández-Ponce, M.T., Casas, L., Mantell, C. \& de la Ossa, E.M. 2015. Use of high pressure techniques to produce Mangifera indica L. leaf extracts enriched in potent antioxidant phenolic compounds. Innovative Food Science \& Emerging Technologies, 29: 94-106.

Ghanbari, D., Niasari, M.S., Khaghani, S. \& Beshkar, F. 2016. Preparation of polyvinyl acetate (PVAc) and PVAc-Ag- $\mathrm{Fe}_{3} \mathrm{O}_{4}$ composite nanofibers by electro-spinning method. Journal of Cluster Science, 27(4): 1317-1333.

Green, D.W. \& Rosales, A. 2002. Mechanical Properties of Wood, in Wood Handbook: Wood as an Engineering Materials edited by D. Bender (United States Department of Agriculture, Madison, Wisconsin, USA), pp. 4-45.

Tan, H., Jiang, L.Y., Huang, Y., Liud, B. \& Hwang, K.C. 2007. The effect of van der Waals-based interface cohesive law on carbon nanotubereinforced composite materials. Composites Science and Technology, 67(14): 2941-2946.

Hadiyawarman, A.R., Nuryadin, B.W., Abdullah, M. \& Khairurrijal. 2008. Fabrication of superstrong, lightweight and transparent nanocomposite materials using simple mixing method. Jurnal Nanosains dan Nanoteknologi, 1: 15-21.

Holbery, J. \& Houston, D. 2006. Natural-fiberreinforced polymer composites in automotive applications. Journal of the Minerals, Metals, and Materials Society, 58(11): 80-86.

Ko, Y.N., Park, S.B. \& Kang, Y.C. 2014. Excellent electrochemical properties of yolk-shell $\mathrm{MoO}_{3}$ microspheres formed by combustion of molybdenum oxide-carbon composite microspheres. Chemistry - An Asian Journal, 9(4): 1011-1015.

Kumagai, S. \& Sasaki, J. 2009. Carbon/silica composite fabricated from rice husk by means of binderless hot-pressing. Bioresource Technology, 100: 3308-3315.

Liu, S., Imanishi, N., Zhang, T., Hirano, A., Takeda, Y., Yamamoto, O. \& Yang, J. 2010. Effect of nano-silica filler in polymer electrolyte on $\mathrm{Li}$ dendrite formation in $\mathrm{Li} /$ poly(ethylene oxide)$\mathrm{Li}\left(\mathrm{CF}_{3} \mathrm{SO}_{2}\right)_{2} \mathrm{~N} / \mathrm{Li}$. Journal of Power Sources, 195: 6847-6853.
Masturi, Swardhani, A.P., Sustini, E., Bukit, M., Mora, Khairurrijal \& Abdullah, M. 2010. High strength lightweight nanocomposite from domestic solid waste. AIP Conference Proceeding, 1284: 59-63.

Masturi, Abdullah, M. \& Khairurrijal. 2011a. High compressive strength of home waste and polyvinyl acetate composites containing silica nanoparticle filler. Journal of Material Cycles and Waste Management, 13: 225-231.

Masturi, Aliah, H., Aji, M.P., Sagita, A.A., Bukit, M., Sustini, E., Khairurrijal \& Abdullah, M. 2011b. Effect of silica nanoparticles on compressive strength of leaveswaste composite. AIP Conference Proceeding, 1415: 90-93.

Masturi, Marwoto, P., Sunarno \& Rustad, S. 2016. Effect of quartz sand on compressive strength of the solid waste composite. AIP Conference Proceeding, 1712: 0500061-0500065.

Nazir, R., Momeni, E., Armaghani, D.J. \& Amin, M.F.M. 2013. Prediction of unconfined compressive strength of limestone rock samples using L-type Schmidt hammer. Electronic Journal of Geotechnical Engineering, 18: 1767-1775.

Okwu, D.E. \& Ezenagu, V. 2008. Evaluation of the phytochemical composition of mango (Mangifera indica Linn) stem bark and leaves. International Journal of Chemical Sciences, 6(2): 705-716.

Pan, J., Yi, X., Zhang, S., Cheng, J., Wang, Y., Liu, C. \& He, X. 2018. Bioactive phenolics from mango leaves (Mangifera indica L.). Industrial Crops \& Products, 111: 400-406.

Rêgo, J.H.S., Nepomuceno, A.A., Figueiredo, E.P. \& Hasparyk, N.P. 2015. Microstructure of cement pastes with residual rice husk ash of low amorphous silica content. Construction and Building Materials, 80: 56-68.

Singh, H. \& Bansal, S. 2015. Effect of silica fume on the strength of cement mortar. International Journal of Research in Engineering and Technology, 4(2): 623-627.

Taghvaei, A.H., Ebrahimi, A., Ghaffari, M. \& Janghorban, K. 2010. Magnetic properties of iron-based soft magnetic composites with $\mathrm{MgO}$ coating obtained by sol-gel method. Journal of Magnetism and Magnetic Materials, 322(7): 808-813.

Volkov, A.V., Myasnikova, N.A., Kolesnikov, V.I. \& Konovich, M.Z. 1990. Molecular interaction in composite materials based on polycaproamide and epoxy resins (Trans.). Mekhanika Kompozitnykh Materialov, 3: 398402. 
Wang, S., Zhang, L., Yan, B., Xu, H., Liu, Q. \& Zeng, H. 2015. Molecular and surface interactions between polymer flocculant chitosan-gpolyacrylamide and kaolinite particles: impact of salinity. The Journal of Physical Chemistry C, 119(13): 7327-7339.

Wang, X.J., Zhang, L.Z. \& Pei, L.X. 2014. Thermal conductivity augmentation of composite polymer materials with artificially controlled filler shapes. Journal of Applied Polymer Science, 131(8): 39550-39559.

Wu, H.X., Li, X.F., Li, R., Li, L. \& Wang, N.L. 2010. Study on anti-oxidative components from leaves of Psidium guajava. Chinese Traditional and Herbal Drugs, 41: 1593-1597.
Zhang, Y., Qian, Q., Ge, D., Li, Y., Wang, X. \& Chen, Q. 2011. Identification of benzophenone Cglucosides from mango tree leaves and their inhibitory effect on triglyceride accumulation in 3T3-L1 adipocytes. Journal of Agricultural and Food Chemistry, 59: 11526-11533.

Zheng, S.T., Wu, T., Chou, C., Fuhr, A., Feng, P. \& $\mathrm{Bu}, \mathrm{X} .2012$. Development of composite inorganic building blocks for MOFs. Journal of the American Chemical Society, 134(10): 45174520 . 
